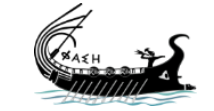

journal.phaselis.org
PHAS KLIS Issue V (2019)
Disiplinlerarası Akdeniz Araştırmaları Dergisi

Journal of Interdisciplinary Mediterranean Studies

\title{
Preventive Conservation and Repair Work at Cibyra from 2010 to 2017
}

Kibyra 2010-2017 Yılları Koruma ve Onarım Çalışmaları

\author{
Esra SAYIN \\ (D) https://orcid.org/0000-0002-8982-0042 \\ Ünal DEMIRER \\ (D) https://orcid.org/0000-0002-2988-0369
}

open 2 access journals

The entire contents of this journal, Phaselis: Journal of Interdisciplinary Mediterranean Studies, is open to users and it is an 'open access' journal. Users are able to read the full texts, to download, to copy, print and distribute without obtaining the permission of the editor and author(s). However, all references to the articles published in the e-journal Phaselis are to indicate through reference the source of the citation from this journal.

Phaselis: Journal of Interdisciplinary Mediterranean Studies is a peer-reviewed journal and the articles which have had their peer reviewing process completed will be published on the web-site (journal.phaselis.org) in the year of the journal's issue (e.g. Issue IV: JanuaryDecember 2018). At the end of December 2018 the year's issue is completed and Issue V: January-December 2019 will begin.

Responsibility for the articles published in this journal remains with the authors.

Citation E. Sayın, Ü. Demirer "Preventive Conservation and Repair Work at Cibyra from 2010 to 2017". Phaselis V (2019) 207-229 http://dx.doi.org/10.18368/Pha.19014

Received Date: 24.04.2019 | Acceptance Date: 11.07.2019

Online Publication Date: 04.09.2019

Phaselis Research Project

www.phaselis.org 


\title{
Preventive Conservation and Repair Work at Cibyra from 2010 to 2017
}

\author{
Kibyra 2010-2017 Yılları Koruma ve Onarım Çalışmaları
}

\author{
Esra SAYIN * - Ünal DEMIRER **
}

\begin{abstract}
The transition from the underground environment, from which architectural remains have been removed, to above ground, causes these artefacts to begin to deteriorate, and the problem of their loss or irreversible damage if precautions are not taken. Therefore, the preservation of architectural remains at archaeological sites together with the "stabilization and improvement" of the current situation are accepted as a generally accepted approach to this problem. In this context, the preventive conservation practises applied during the scope of the restoration work consists of protection, but it is observed in the years after the repair that external factors will damage the work. With this in mind, studies on the conservation and restoration of the movable or immovable cultural assets, which have exposed in excavations carried out in the ancient city of Cibyra since 2009, were carried out immediately. In this study, the conservation and restoration practices concerning the immovable cultural assets unearthed in the course of the archaeological excavations between 2010-2017 are discussed.
\end{abstract}

Keywords: Cibyra, Preventive Conservation, Architectural Conservation, In-situ Conservation

Öz: Toprak altından çıkarılan arkeolojik eserlerin yeraltındaki anaerobik ortamdan yer üstündeki atmosferik ortama geçişleri, eserlerin bozulmaya başlamasına ve önlem alınmadığında yok olma tehlikesiyle karşı karşıya kalmalarına neden olur. Bu nedenle arkeolojik alanlardaki mimari kalıntıların veya taşınır eserlerin korunması ve mevcut durumlarının "istikrara kavuşturulması ve iyileştirilmesi" genel kabul gören bir yaklaşımdır. Bozulmaları önleyici restorasyon ve konservasyon çalışmaları da, kapsamlı onarım projelerinden ziyade, mevcut durumu iyileştirip sabitlemeye yönelik acil koruma önlemleri içermektedir. Bu yaklaşımla, 2009'dan beri Kibyra antik kentte ortaya çıkarılan taşınır veya taşınmaz kültür varlıklarında önleyici koruma uygulamaları, uluslararası koruma ilkelerine ve özgün malzemeye sadık kalınarak, en az müdahale anlayışıyla, kazılarla eşzamanlı olarak derhal gerçekleştirilmektedir. Bu çalışmada, 2010-2017 yılları arasında yapılan arkeolojik kazılarda ortaya çıkan kültür varlıklarının önleyici koruma ve onarım uygulamaları belgelenmiştir.

Anahtar sözcükler: Kibyra, Önleyici Koruma, Mimari Konservasyon, Yerinde (In-situ) Konservasyon

\section{Introduction}

In the conservation-restoration works carried out in Cibyra ${ }^{1}$, in general, the protection of the structure or the work as well as the preservation and repair with the original material are taken as the basis, and the work plan has been developed within this framework. In conservation-

* Research Assistant, İstanbul Gelişim University, Department of Restoration and Conservation, School of Applied Sciences, isTANBUL. esayin@gelisim.edu.tr | (D https://orcid.org/ 0000-0002-8982-0042

** Dr. Lecturer, Mehmet Akif Ersoy University, Gölhisar Vocational High School, Department of Architectural Restoration, BURDUR.udemirer@mehmetakif.edu.tr| (1) https://orcid.org/0000-0002-2988-0369

1 For detailed information about Cibyra see: Özüdoğru 2018a. 
restoration practices, the principle of preserving the original material ${ }^{2}$ forming the structure, has been meticulously handled as priority, applying the principles of international protection ${ }^{3}$.

In accord with these objectives, at Cibyra when excavation works have been completed, the first step in the conservation and restoration works on the buildings is their documentation. Before conservation the artefacts are documented graphically and photographically. All are documented before, during and after the process of consevation ${ }^{4}$. This practice itself provides an set of important documents that can be used to identify problems and follow the success or otherwise of conservation applications by means of the record provided by the drawings and photographs of the work 5 .

\section{Stadion}

The conservation and restoration practices carried out at the Stadion ${ }^{6}$ in 2006, where archaeological excavations were initiated, were conducted with the aim of protecting the existing remains with limited interventions, such as cleaning, maintenance and strengthening from 2010 until 2015. The areas where the protection and repair work has been carried out at Stadion to date, in line with these objectives are: the northern and southern areas of the building include the cells where the western seating steps were placed and the reinforcement of the eastern retaining wall. In the northern area of the building, protective measures were carried out on the northern walls. The walls in the north were raised up to the in-situ level and in the south of the building, static consolidation practices were carried out on the walls of the seven arches. In the conservation practices conducted in the area, the walls were repaired with a mortar in which was hydraulic lime-based and coarse particles and powdered aggregate were used in a ratio of $1 / 3$. In addition, the cells in which the western seating steps were placed were protected with original stones along the same line with this hydraulic lime-based mortar ${ }^{7}$. This practice is important in terms of strengthening the walls that can be damaged by ice and rain and pose a danger to the protected part of the structure.

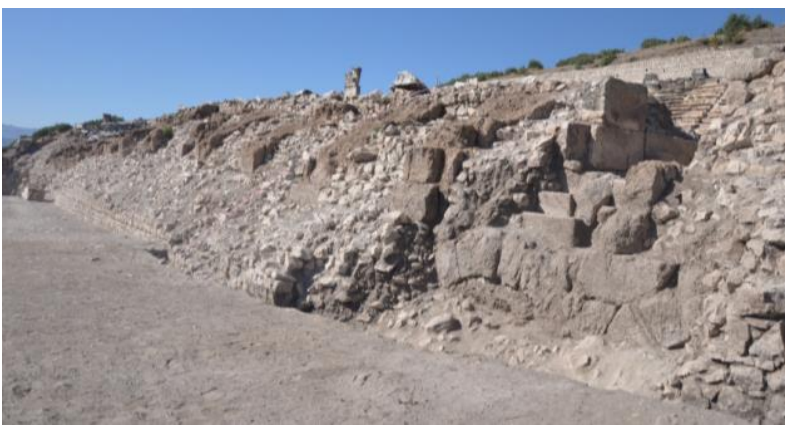

Fig. 1. Stadion retaining wall, before conservation (Kibyra Excavation Archive)

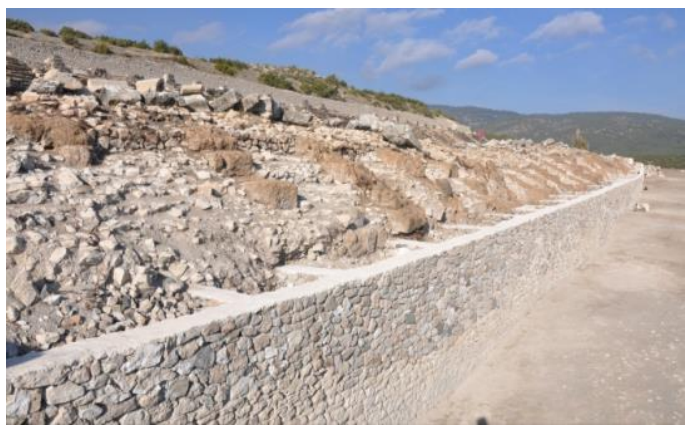

Fig. 2. Stadion retaining wall, after conservation (Kibyra Excavation Archive)

In the eastern part of the stadium, the deterioration of the retaining wall, which is parallel to the cavea and consists of rubble stones with lime additive, caused the need for repair and

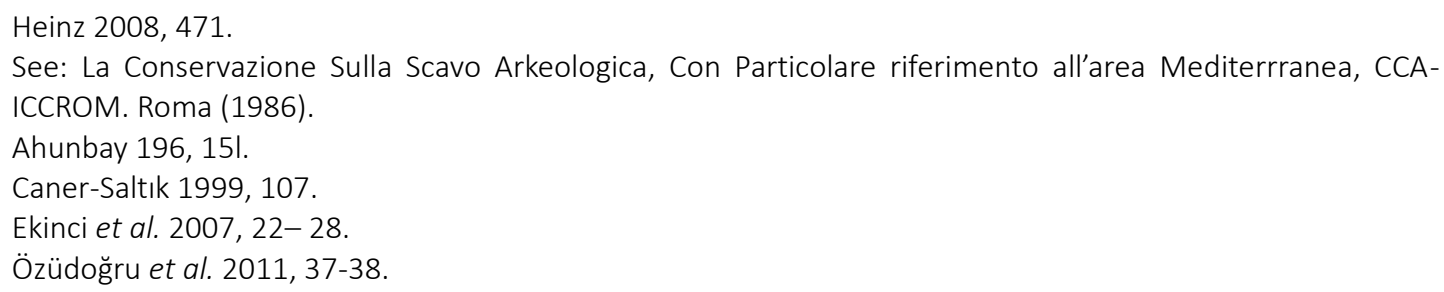


anastylosis studies of the area in question ${ }^{8}$. In consequence, the inner cavea with the retaining wall to the east of the cavea, built to increase the resistance of the internal cell walls, were strengthened and at the targeted point the repair applications reached its goal. Thus, the retaining walls in the cavea and adjacent structures, which make up the eastern part of the building, have become protected and the structure has become an integral feature (Fig. 1-2).

\section{Martyrion}

The martyrion, located to the east of the Propylon of the Stadion, experienced great damage when the propylon collapsed in a major earthquake. Despite this destruction, the main walls of the building, the vaulted tomb beds forming the grave chamber at the bottom and support of the upper floor were found to be quite intact (Fig. 3). Therefore, this structure with the architectural features of Late Antiquity of the city, with the necessary information concerning the heavily damaged Martyrion underwent urgent intervention and was taken under protection. In addition, the loss of the stone rows in the structure, the depressions and the deformation of the ruins constitute a risk factor affecting the soundness of the remaining parts, as well as disturbing the aesthetic appearance ${ }^{9}$. The aim was to protect the structure urgently within the scope of the conservation-restoration works of 2012 due to the fact that such deteriorations will increase in the process and will cause dangers that will manifest itself in new ruins ${ }^{10}$.
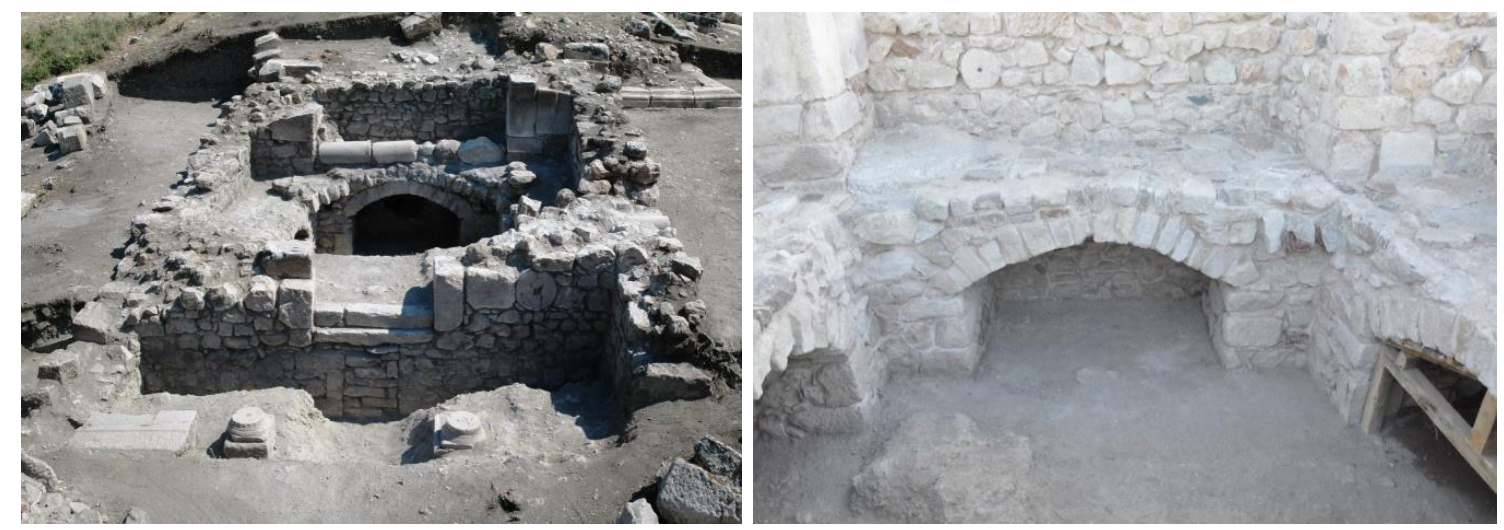

Fig. 3-4. Martyrion, before and after conservation (Kibyra Excavation Archive)

It was decided that the most effective solution for the deformation of Martyrion was the restoration of the joint fillings of the walls of the walls constructed with rubble masonry using lime additive mortar. With this in mind, mechanical cleaning applications of the areas where spills occur in the wall joints had priority. In addition, the removal of the rubble stones damaged by natural conditions in the upper part of the main walls of the building were within the scope of these pioneering works. With this, the first stage of the works, all the wall joints on the inside and outside of the structure were made ready to be refilled. The second stage of the works consisted of filling the wall joints with the lime-based mortar compatible with the original. The content of the mortar applied was hydraulic lime, 0-3 $\mathrm{mm}$. The mortar comprised white sand, natural colorant and strength-enhancing sieved brick/tile powder, ready-to-use special masonry mortar and white acrylic. The obtained mortar was filled by pressing into all the wall joints prepared for application. In addition to this pointing application, a supporting wooden

\footnotetext{
Özüdoğru 2012, 49.

Şener 2013, 612.

Özüdoğru 2010, 39.
} 
construction was made, on the lower part of the vault in order to strengthen the vault of the door on the north facade which provides access to the lower burial chamber (Fig. 4). As a result of the conservation practices carried out, the building has become soundly integrated and has been made more resistant to natural conditions.

\section{Agora $1^{\text {st }}$ Terrace Street}

In-situ protection is a method of protection that can be accomplished through the preservation of a whole area. Clear solutions for a single object in the field may provide an unhealthy temporary protection, as well as risking the preservation of works and even of the area. For this reason, Cibyra Agora I. Conservation and restoration applications began on the Terrace Street in 2009 and continued until 2017, including all excavation areas, the Monumental Entrance Gate, the Macellum, late period shops, eastern stoa opus spicatum flooring ${ }^{11}$ and protection was carried out in Nymphaeum / Castellum.

\section{1. Monumental Gate}

Excavations in Agora, which has an important position in the city where merchants and artisans offered their products for sale, began in 2009. For reason of its importance in this context, it was decided to raise the monumental gate in the northeast corner of Agora, which had been heavily damaged in the Late Antiquity, during the 2009 works $^{12}$.

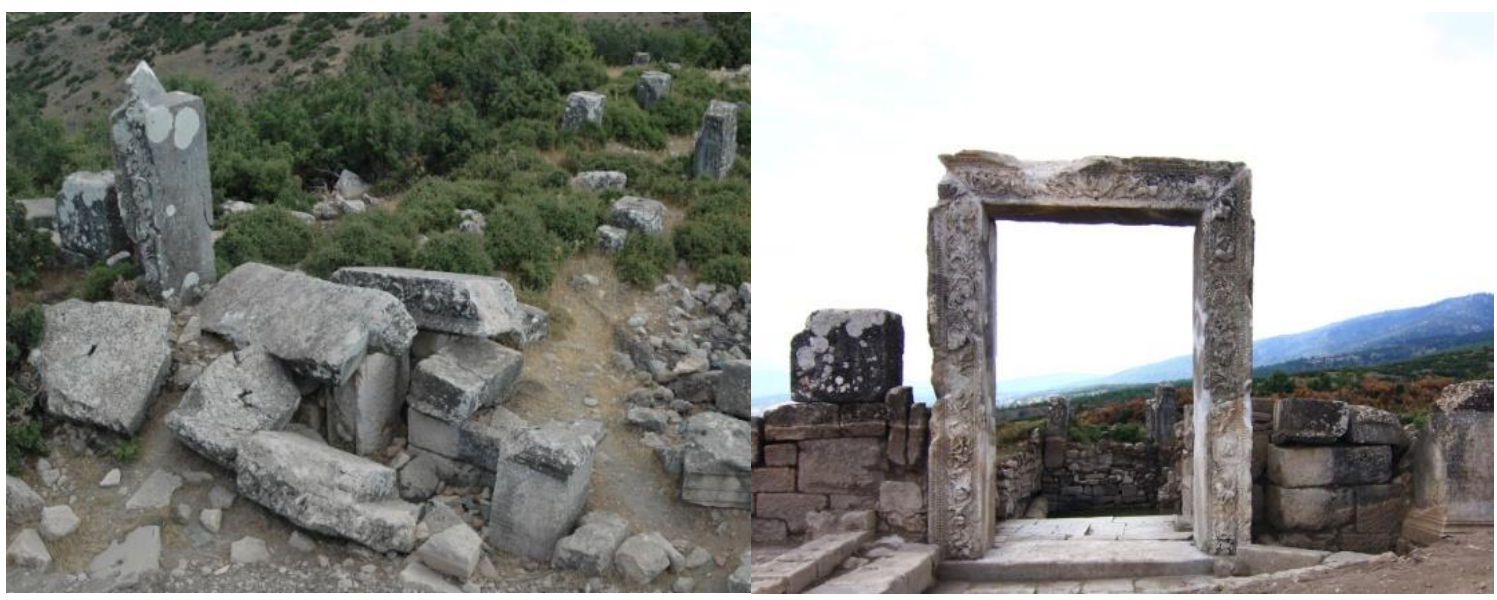

Fig. 5-6. Monumental Gate, before and after conservation (Kibyra Excavation Archive)

As a result of the excavation workss carried out in the area, the eastern jamb of the door and the western jamb in the form of two pieces beneath the lintel were fully exposed (Fig. 5). These four parts of the door could be removed from the finds and repaired. The first step of the application was the integration of the western jamb weighing about 3.5 tons. Reinforcement of stainless steel or fiberglass rods (more commonly accepted) at certain points during the bonding of high and heavy loads is necessary for the durability of the process ${ }^{13}$. For this reason, the two main parts were repaired using three $18 \mathrm{~mm}$. thickness and $40 \mathrm{~cm}$. in length fiber rod bars and two-component epoxy-based resin ${ }^{14}$. After the lintel and jambs were assembled and

11 The protection and repair work of the Opus Spicatum floor coverings has been the subject of a comprehensive study by Esra Sayın. For detailed information; Sayın 2018, 99-117; Sayın 2015.

12 Özüdoğru et al. 2010, 42.

13 Şener 2013, 619.

14 Özüdoğru et al. 2010, 44. 
positioned at their original location, the joints at the joint points were filled using an acrylic mixture hydraulic lime mortar ${ }^{15}$.

After the completion of the integration of the stone surface came the cleaning stage. The aim of the surface cleaning was to reveal the original color and texture of the door elements that had become covered with a microbiological patina. For this reason, in the cases where the ammonium bicarbonate applied to the harder dirt layers, selected according to the type of dirt and which proved ineffective in removing parts of the surface patina, EDTA (Ethylene Diamintetra Acidic Acid) was used locally in certain places. The microbiological patina and dissolving dirt was cleaned with a scalpel, soft brushes and dentist tools and was then wiped with a sponge and removed from the surface. After this treatment, the surface was washed with pure water removing the chemical traces. As a result of these systematic interventions, the aim of returning the door frame to close to its original state and to protect it in its original location was realised (Fig. 6).

\section{2. Macellum (Fish Pond)}

Another conservation-repair work on the $1^{\text {st }}$ Terrace Street in 2011 was carried out in the fish pond (Macellum) located on the $50^{\text {th }}$ meter of the West Stoa. Located on the street between the $7^{\text {th }}$ and $8^{\text {th }}$ doors of the West Stoa, its outer contours measure $3.60 \mathrm{~m}$. X $1.30 \mathrm{~m}$. The repair work of the pool was measured by combining curved blocks of two parts at the south end. After the joining of the surviving parts, the missing parts on the two sides of the pool were completed by curving at the original angle for the purpose of integration (Fig. 7).
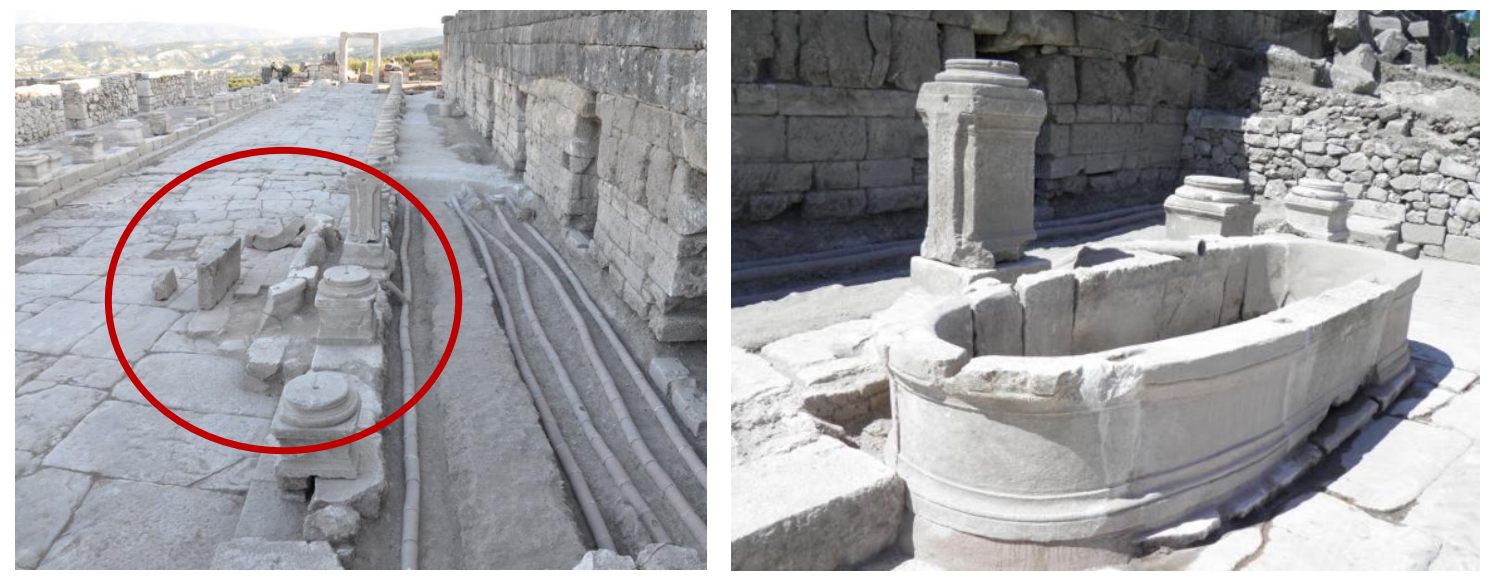

Fig. 7-8. Macellum, before and after conservation (Kibyra Excavation Archive)

In order to retain the color and antique texture in these applications, in the hydraulic lime additive mortar a thick tile powder was used. In addition, in the integrated areas, the upper and lower profiles are partially machined in accordance with the in-situ parts, so that the integrity of the original parts and integrated areas is ensured. Following the integration of the outer contours, the brick work of the pool floor was re-arranged on the renewed floor with hydraulic doped lime mortar for the purpose of reinforcing, and in accord with the impressions marks on it and the missing parts were completed using the original material. In the final process, it was found that the line of pipe adjacent to the podium of the north-south axis postaments was connected to the pond through the original material uncovered by the excavations and thus the purpose of presenting the pool with its original appearance in antiquity was achieved (Fig. 8).

15 Özüdoğru et al. 2010, 44. 


\section{3. Late Antique Shops}

One of the protections and repair applications carried out in the $1^{\text {st }}$ Terrace Street was conducted in the late antique shop walls in the East Stoa, from the year 2011 to the present day (Fig. 9). As a result of archaeological excavations, precipitations and debris formed by precipitation and external influences on the walls of buildings are frequently encountered in excavation areas. As a matter of fact, in buildings with such problems, completely or partially collapsed in the wall bonds which are exposed through excavation and when protective measures are not taken causes the loss of originality as a result of the loss of the bonding material ${ }^{16}$. In the shops of the Terrace Street, first steps were taken in order to prevent this deterioration. As a result of the strengthening of the rubble mesh walls to the protected level limited the destruction of the walls to minor rather than serious dimensions. Before conservation-repair works, not only the demolitions of the upper lattice of the walls, but also the joints made with the lime mortar between the rubble stones used in the walls were partially poured and the soil was filled in these parts. Therefore, the first stage of the work in the field of cleaning the soil between the joints and, at the same time, the risk of the falling out of the rubble stones were removed through cleaning the plant roots together with walls to be prepared for pointing.

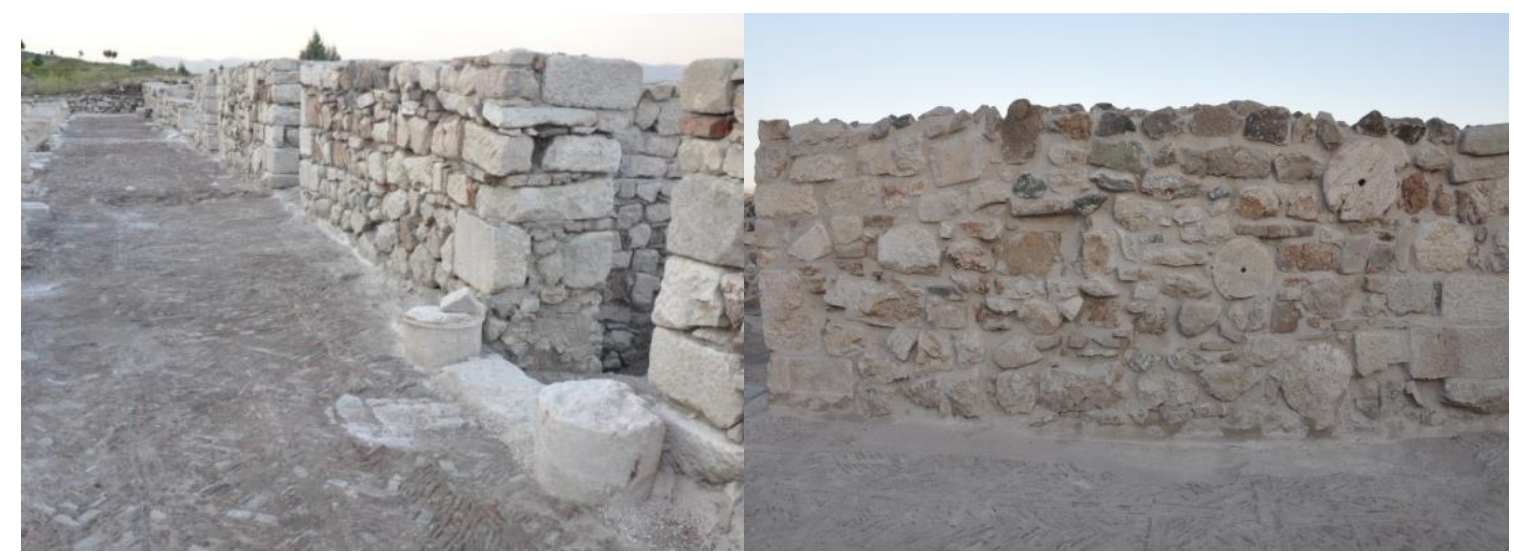

Fig. 9-10. Late antique shop walls in east stoa (Kibyra Excavation Archive)

After these initial operations, in the second stage a highly qualified and high strength grouting mortar was prepared in accord with the lime mortar used in the building. The content of this mortar comprised: 0-3 mm. sintered crushing sand, hydraulic lime, bricks and tile shaft as colorant, white acrylic and strength fortifying mortar. After the dough prepared for the pointing application was pressed into the previously used grouting spaces, the settling time was expected to be completed. After that, the burrs were cleaned in the polishing process and the wall joints were given a natural appearance. At the same time in the upper part of the wall's deformation, fallen and scattered areas at risk, pointing protection was completed (Fig. 10). These conservation works carried out on the walls of the late-period shops were carried out systematically on those walls exposed as a result of excavations every year, and in consequence, the course of deterioration through exposure through excavation was impeded and the original form of the walls was restored. 


\section{4. Furnace}

Within the scope of the 2014 conservation and repair applications carried out on the Ist Terrace Street, practices were carried out to increase the strength of the furnace located in shop no. 7 in the eastern stoa. In order to increase the strength of the structure of the furnace and to prevent the dispersion of the top cover system, operations began with documentation and photography. Then, as a preventive protection method for the joint problem observed in these types of structures, the old mortar, which had weakened in the joints of the bricks and the rubble stones, was cleaned with mechanical methods.
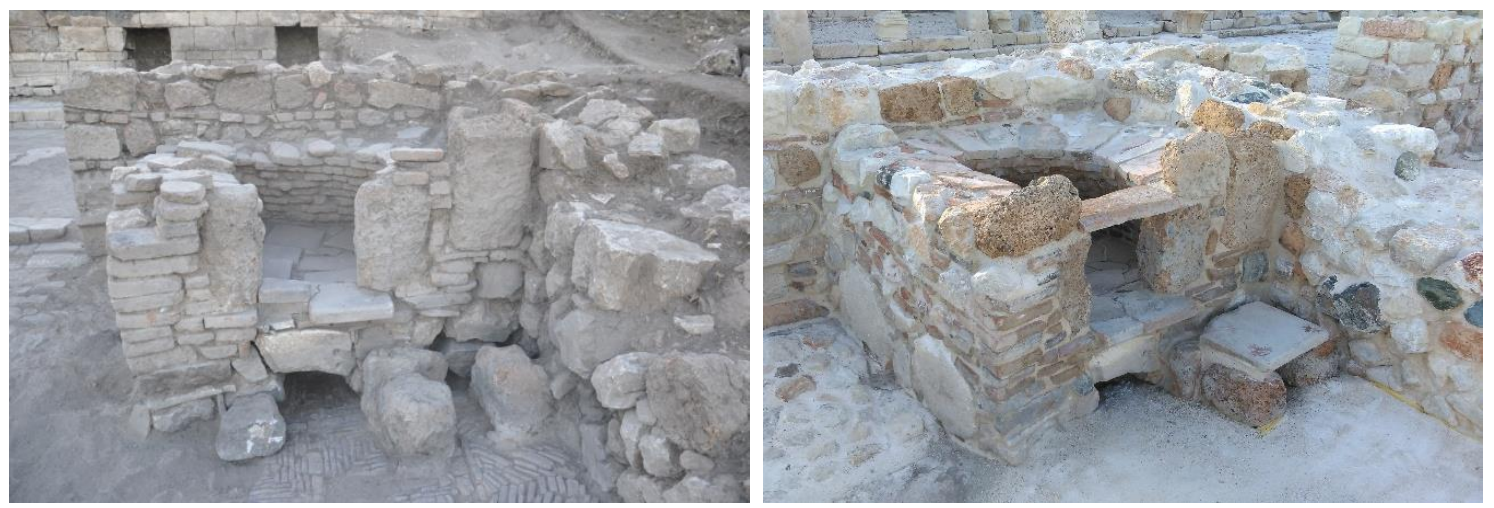

Fig. 11-12. Furnace, before and after conservation (Kibyra Excavation Archive)

Coarse aggregate and $1 / 3$ ratio lime mortar was prepared for pointing applied to the joints by pressing. After completion of the pointing, the burring between the joints was removed by mechanical means. In addition to these operations, the upper part of the kiln was preserved with a new binding order employing its original material. As a result of the operation of protection and repair, the furnace structural problems were solved with the least possible intervention (Fig. 11-12).

\section{5. Castellum/Nymphaeum}

The last protection-repair work of 2015 was conducted at the Castellum-Nymohaeum in the Ist Terrace Street. Work began in 2014 in order to increase the strength of the varieties of materials and parapet walls of the Castellum / Nymphaeum ${ }^{17}$, which was uncovered at the $80^{\text {th }}$ meter of the western stoa, and to prevent deterioration from natural causes of the excavated structure. The preventive protection measures and repair applications carried out in the scientific sense aimed to protect the in-situ künk, pool floor, parapet walls and plastered areas over the long term, not to undermine the aesthetic appearance and to maintain the integrity of the technical information it embodies ${ }^{18}$.

Preventive protection and repair work was initiated in line with these objectives, the area was first documented by photographing the area and the first case distortion scale was removed. Following documentation studies, the first phase of conservation work initiated in the area was the repair of the parapet blocks surrounding the structure. During the mechanical cleaning applied to the parapet blocks, by using fine-tipped tools and compressors, the filling of

17 For a more comprehensive architecture definition and function of the building see: Baytak 2015, 667-75.

18 Özüdoğru 2018, 141. 


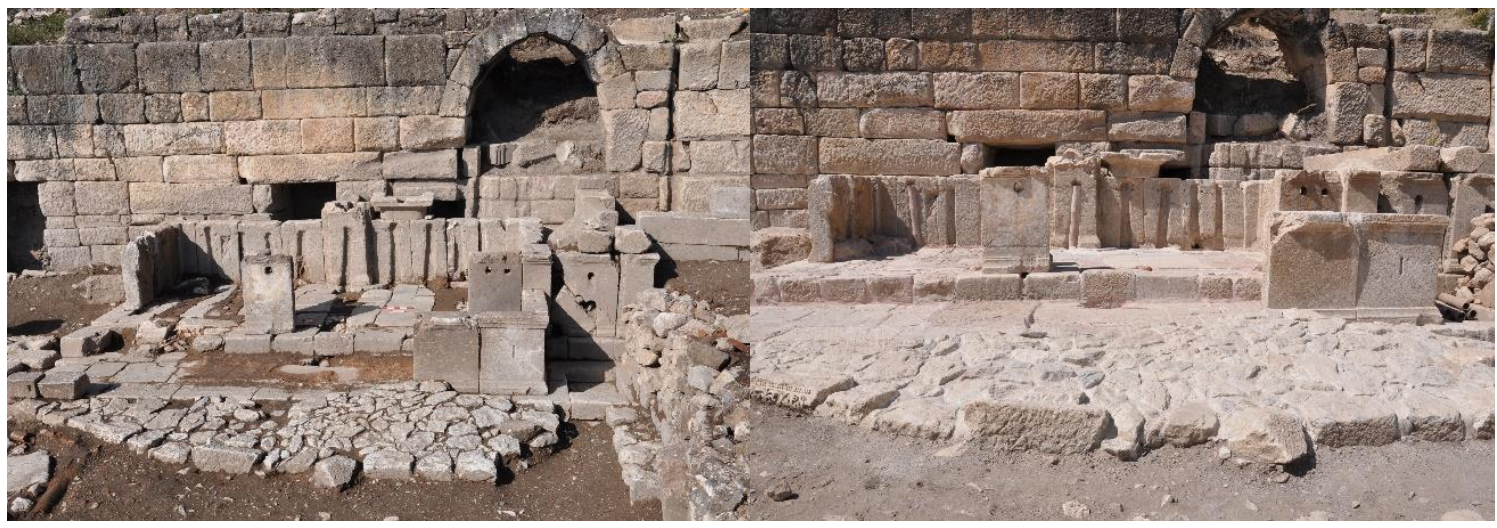

Fig. 13-14. Castellum/Nymphaeum, before and after conservation (Kibyra Excavation Archive)

the surface cracks on the blocks and the spaces between the joints were cleaned and the fractures on these cracked blocks were determined. Then the broken pieces and broken blocks are glued into their original places with the help of a two-component epoxy-based resin. The joints between the parapet blocks were cleaned through mechanical cleaning and the cracks on the surface were filled with abundant water and filled with antique restoration mortar with a low mechanical strength.

After the passive protection applications to the parapet blocks, the floor blocks of the structure and the partial brick pavement in the floor were repaired. At this stage, the bricks that were heavily damaged in the broken brick flooring covering a part of the floor of the first pool were removed and replaced with amorphous bricks from the original material. The next stage of the floor conservation was cleaning the filling soil accumulated between the joints with the help of fine tipped tools and compressors. After cleaning, the floor joints moistened with plenty of water were then filled with a lime binding mortar. On the floor of the structure and the partially preserved coating mortar around the border mortar application of the existing plastered areas were prevented from their rupture, dispersion and loss, and the structure conserved with limited intervention.

Following the ground consolidation practices, the conservation-repair process of the partially preserved pipe rows in the western parapet walls of the first pool was initiated. In this work, the 4 pieces of pipe, which were seen to continue towards the grooves on the western parapet wall with the help of the elbow-shaped pipes, were raised into their original places and fixed to the parapet wall with the help of hydraulic lime-based mortar. In the other 8 grooves, the elbows were protected in their current state. This repair to the pipes is important for the visitor's understanding of the technology of the pool.

Initiated to conserve and preserve through the protection and repair applications carried out as described above, the resistance of the pool and the ponds connected to the pool to the adverse weather conditions of the winter months, minus temperatures, snow and ice, has increased and further deterioration from both the natural conditions on-site and visitors has been prevented. In order to enable the visitor to perceive the technical characteristics of the building, its visualization, the original material and the texture and the works were completed (Fig. 13-14).

\section{Main Street}

The excavation and anastylosis studies were carried out in 2017 with the aim of the preservation and consolidation of the current situation in the stepped section of the main 
street, which was laid as a result of excavations carried out in 2012, at the intersection of the 7 $\mathrm{m}$. wide east-west oriented main street with the Terrace Column Street (Fig. 15).

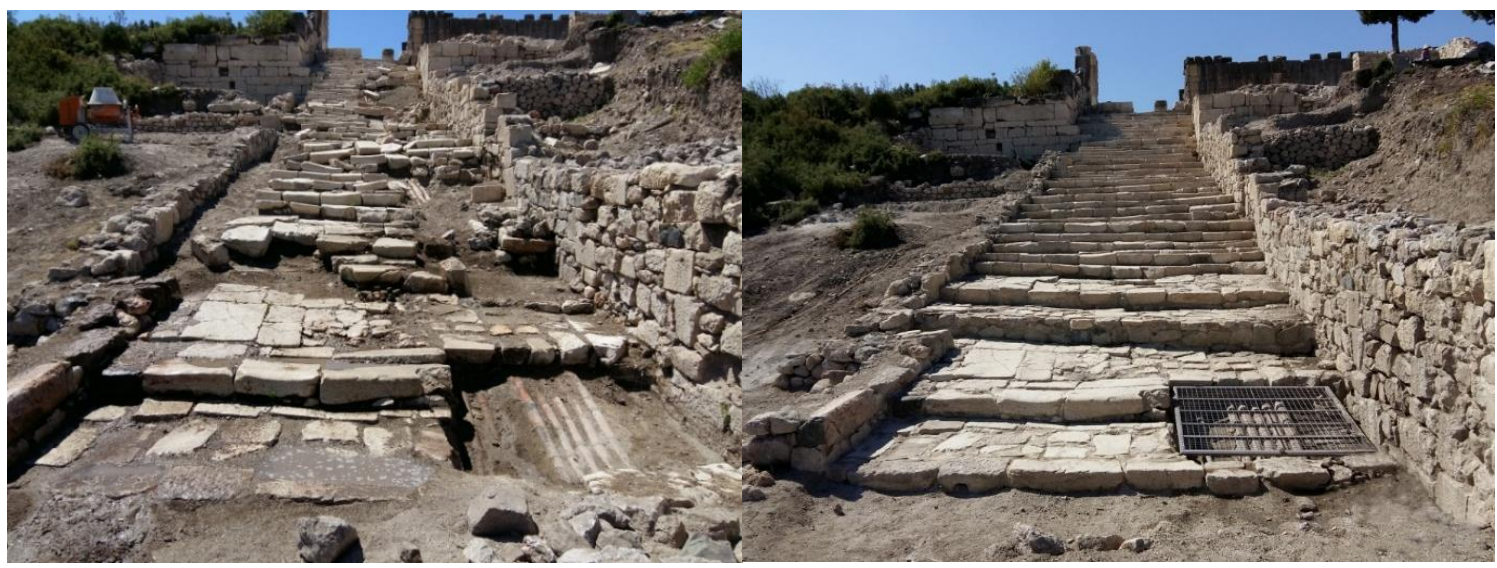

Fig. 15-16. Main Street, before and after conservation (Kibyra Excavation Archive)

In the first phase of the conservation-repair operations, those steps which have been heavily damaged in Late Antiquity and most of the blocks that had been removed and reused in different areas, were documented over previous excavation seasons. Then, the current situation determination of the distortions and documentation studies were carried out and protectionrepair methods were then applied. The current number of steps is 35 , each of which varies in size. The steps are different from those of the local limestone and the earthquakes, weather conditions and environmental impacts have resulted in abrasions to the surface, the formation of capillary cracks and the inevitable result of all these elements. In order to prevent further destruction of the blocks forming the steps by taking into account the negative factors on the material, the repair work began in parallel to the original building material of the Late Period wall structures extending in the east-west direction of the steps and which remained partially intact. In addition, the current state of the city's waste and clean water system, which lies in the east-west direction, has been preserved. Some of these protected areas were exposed to preventive protection measures in order to determine and display the city's sewerage and water system. Late period walls, which extend in the east-west direction, with irregular rubble stones and reused architectural pieces parallel to the stair steps, were reconstructed and reinforced in accord with the original through acrylic blended hydraulic lime mortar prepared in the ratio of $1 / 3$ in the scope of simple repair work. The content of the mortar used in the application; 0-3 $\mathrm{mm}$. under-sieve white sand, natural colorant and strength-enhancing property drawn 0-5 mm. sieved brick/tile powder, hydraulic lime, ready-mixed special building mortar and white glue (PVA) were included in the mixture. In addition, the distortions in the joints of the walls and in the stair treads were cleaned through mechanical methods and the original structure was maintained and repaired with hydraulic lime-based filler mortar with high strength used as the binding mortar.

Earthquake damage, the weather conditions and environmental factors resulted in ground movement and the distorted steps, and so, using the previously identified original blocks in accordance with the scientific rules with the application of anastylosis, a 1/3 ratio prepared with acrylic mixed hydraulic lime mortar employed for repair works. During this study, blockage was made in order to increase the strength of the lower part of the displaced step blocks and then the blocks were aligned to protect it against harsh climatic conditions, including ice expansion 
and to prevent water leakage through the joint gaps. After these conservation operations, the areas of mortar application were soaked through the sprinkling technique for a few days to increase the strength of the mortar and to prevent cracking. Thanks to the protection, repair and anastylosis studies carried out on the stairs of the Agora $1^{\text {st }}$ Terrace Street within the framework of scientific rules, the current state of the building was taken under protection and the structure was comprehensively understood and conserved (Fig. 16).

\section{Late Antique Bath}

The conservation and restoration work conducted in the Cibyra Late Antique Bath ${ }^{19}$ in $2012^{20}$ were carried out in order to preserve and consolidate the building in its present state (Fig. 17). In order to maintain the originality and characteristics of the structure and to protect it with the least intervention, the necessity of repair applications in all parts including the caldarium, tepidarium, frigidarium, apodyterium and the main walls surrounding the structure was accepted and studies began with documenting procedures such as drawing and photography.

In those buildings where excavation works were completed, all the walls in the open air have been conserved in order to prevent the destruction seen in the joints and upper parts of the walls, which constitute the main plan of the building, with the understanding that if they remained unprotected, regardless of the materials with which they were are constructed, they would deteriorate. The aim being to first protect and stabilize the outline of the structure. As in related areas work began with the cleaning out of grout mortars with low resistance, cleaning these parts with plenty of water and thus making them ready for pointing. The content of the mortar used in this repointing was: hydraulic lime, 0-3 $\mathrm{mm}$. sieved white sand, natural colorant and strength-enhancing property drawn 0-5 $\mathrm{mm}$. The tile shaft consisted of a special masonry building mortar and white acrylic, which were included in the mixture. This prepared hydraulic lime-based filler mortar was applied to the wall joints of the structure with a great care and then the grouting on the surface was cleared by mechanical means as the mortar reached optimum consistency. This pointing application was based on protecting the destroyed walls and has reduced the problem without causing any change in the original condition of the building, while the antique-natural appearance of the walls has been preserved.

Following these documenting-conservation-repair operations, which were completed on the outlines of the building, conservation-repair work began in the main places that make up the bath. In this repair work priority was given to the Caldarium, to the floor of the field (hypocaust) and the columns (pilae) carrying the pilae supported floor of the structure. Because such materials are found to be more sensitive than architectural remains, because they have lost their support and protection when excavated, and because they are the elements that directly reflect the functions of the building sections ${ }^{21}$. Therefore, the pilae bricks, which were heavily damaged formed the first stage of the works initiated in order to protect the existing remains in-situ and prevent fresh deterioration, were removed from their places and thus the emptied hypocaust floor was reinforced by the re-blockage study. The large pilae bricks on this solid ground were placed in their original place by using the binding properties of the hydraulic limebased mortar, taking into account the field drawings made over previous years.

19 For more information on the Late Antique Bath, see: Özüdoğru-Tarkan 2018, 175-211.

20 Özüdoğru et al. 2013, 54.

21 Şener 2013, 621. 


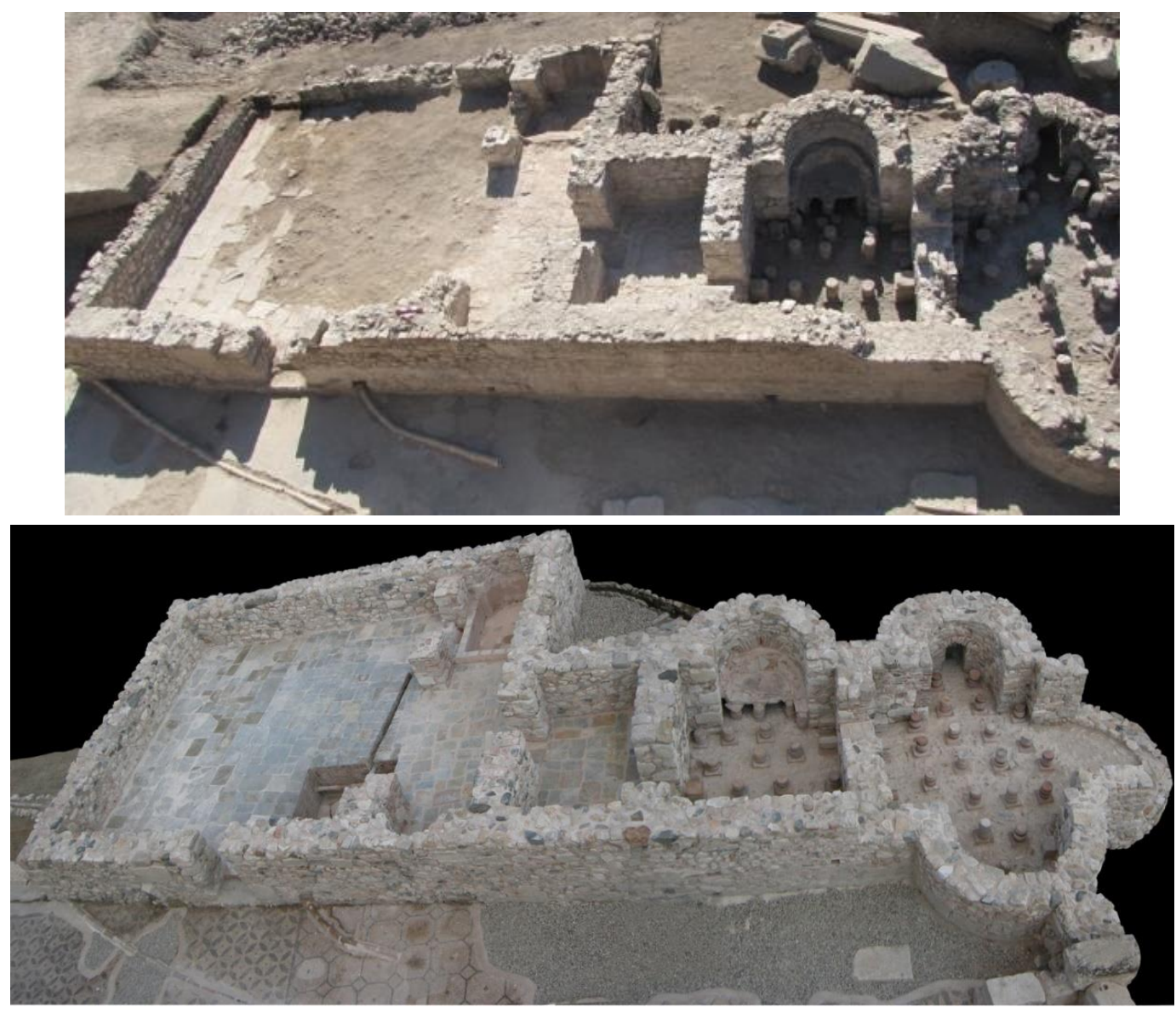

Fig. 17-18. . Late Antique Bath, before and after conservation (Kibyra Excavation Archive)

In addition, a quadrilateral planned section was formed in the south-west corner of the room in order to expose the water system of the bath in the apodyterium and the water pipes were structured according to their direction. Thus, the water network system of the building is presented to the attention of the visitors in a clearer manner. Thus, the structure has been completely conserved against negative natural effects, the existing deterioration has been stopped and new deterioration has been prevented and the baths can be safely presented to visitors (Fig. 18).

\section{Odeion}

Between the years 2012 and-2017 during the Cibyra Excavation and Conservation-Repair works included the mosaic of the stoa, the orchestra mosaic and the seating of the odeion.

\subsection{Mozaic Pavement of Odeion}

The project titled "Cibyra: A New Brand in Cultural Tourism,", in the name of Cibyra Excavation Directorate and on behalf of Mehmet Akif Ersoy University was considered worthy of being supported by the Western Mediterranean Development Agency (BAKA) in 2011. The most important pillar of the project was the cleaning, conservation and restoration of the 560 square meter mosaic pavement covering the floor of the stoa in front of the Odeion. In this context, the studies carried out with the approval of the Antalya Cultural Heritage Preservation Board have been successfully planned in order to prevent damage caused by natural conditions and external effects and these were implemented by the İstanbul Anka Restoration company. 
Generally, the steps that should be followed for all movable-immovable works are valid for the Cibyra Odeion stoa mosaic and were applied respectively in the form of diagnosis, documentation and protection-repair operations. Firstly, preliminary studies related to the work, various analyzes and investigations identified problems in general and in particular parts of the work. Some of these problems, the separation and gaps in the tessera bed, the disintegrations in the edge bands and the tessera losses occurring, the collapses caused by the water channels leading to the late bath structure, the erosion caused by the surface dirt caused by the collapse and fire damage to the inscription panel in the north of the mosaic. These problems identified during the diagnosic phase were quantified through photographs and drawings, and the work was divided into sections with a square system consisting of equal sections. The planned working framework for restoration applications consisted of injection applications, consolidation of edge bands, renewal of lost tessera areas, the removal of collapsed areas and surface cleaning.

In principle, interventions aimed at in-situ preservation of mosaics were filling the gaps in the tessera bed with injection applications (Fig. 19). In this application, the injection holes opening into the gaps were first injected with a mixture of alcohol and water, thus opening the micropores. Then the mortar mixture prepared from hydraulic lime and a very fine aggregate was injected and the surfaces of the application were softened with wooden wedges and thus tesselatum and nucleus / rudus layers were reunited. With this consolidation study, tesselatum, nucleus and rudus layers, which had gap and disintegration, were re-connected with injection mortar ${ }^{22}$.

After the injection studies, the border was applied to prevent possible dispersal of the environment and the loss of tesserae. In such studies, when selecting consolidation and curb mortars, materials that are closest to the original grout content should be used according to their thermodynamic property and water permeability. For this reason, the edge bands and end points $20 \mathrm{~cm}$. width and $25 \mathrm{~cm}$. a solid lime and a stone lime-based mortar were used to stabilize it. In order to withstand the mechanical stress caused by the climate, the material of Primal AC -33, which has the flexibility, was mixed with the mortar. This application is important in terms of forming the support that protects the existing tesselatum layer from the edges and ties it to the lower mortar layer. In order to prevent the loss of detail after the ground consolidation and border applications, the empty areas were completed with the original tessars recovered during the excavations. During this application, a mixture of hydraulic lime and Primal AC-33 based mortar was applied on the parts with a loss of tessera and the tesserae were arranged on the mortar.

Calcification and blackening caused by old or new fires in mosaics decreases the resistance of tesserae to natural conditions and causes decomposition ${ }^{23}$. For this reason, the removal of dirt and fire layers formed by soluble salts and soil materials on the surface of the stoa floor exposed to antique fire was accepted as the second stage after structural repair applications of the flooring, by using chemical materials and mechanical methods. This process is also carried out to remove the salt on the surface and to prevent erosion due to this salt. During application, the rough layers on the surface were prepared by mechanical hand tools (scalpel, dentist tools, soft brushes etc.) and prepared for surface chemical cleaning. Subsequently, a mixture of AB-

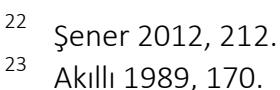


$57^{24}$ was prepared and continued until all layers were removed or minimized. At the end of this process, the surface was rinsed in abundant water and made free of chemical effects. Then, as the result of high salt measurements on the surface, paper pulp material was applied to the surface and these salts were absorbed into the paper pulp.

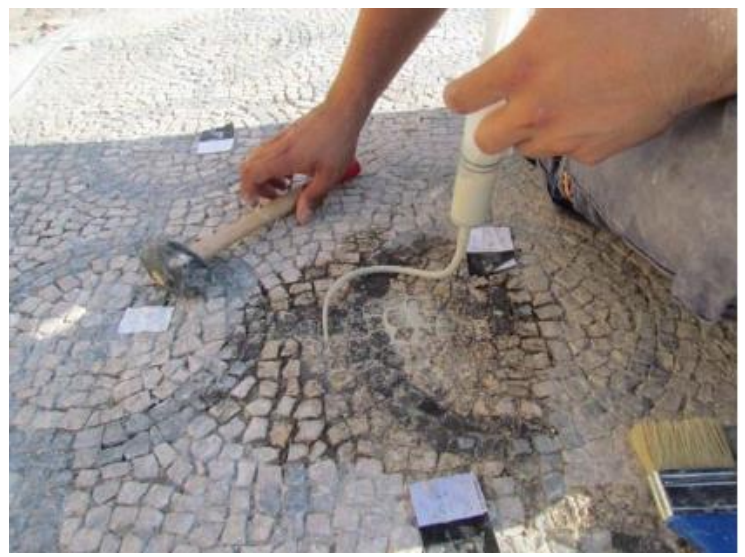

Fig. 19. Mozaic pavement of Odeion, injection (Kibyra Excavation Archive)

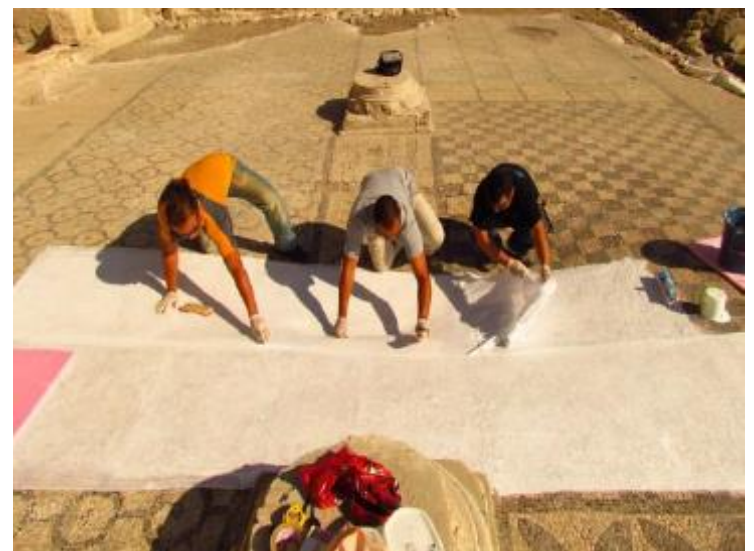

Fig. 20. Removal of collapsed areas (Kibyra Excavation Archive)

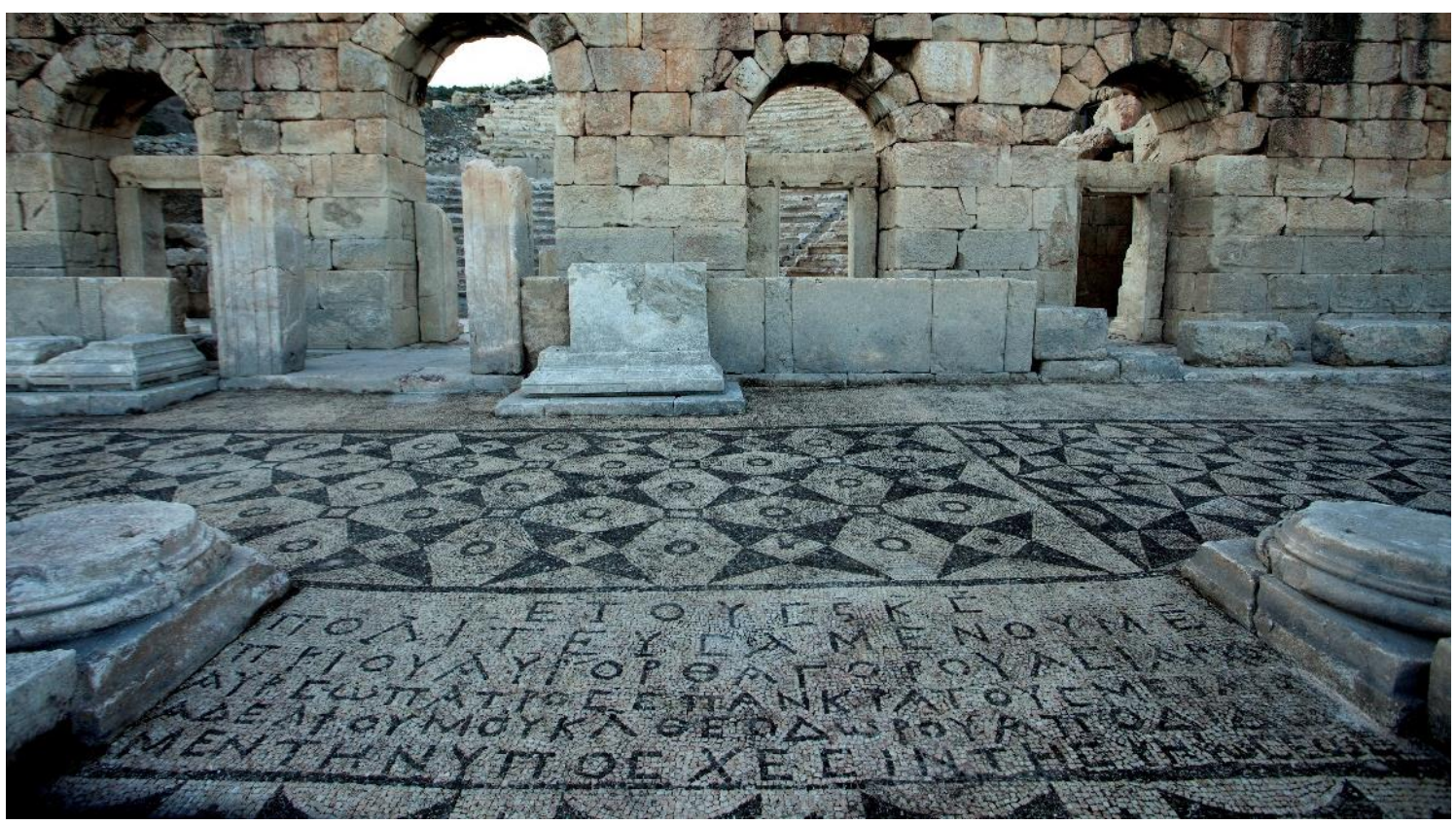

Fig. 21. Mozaic pavement of Odeion, after conservation (Kibyra Excavation Archive)

The last restoration practice in the area was the relocation of the collapse in the south wing of the mosaic and the place where the inscription was found. In this local application, 1/1 scale drawings of the collapsed panel were made and then PVA (polyvinyl acetate) was applied to the surface and the first layer was glued to the first layer and American cloth (thick white cotton cloth) was attached to the second layer (Fig. 20). The boundaries of the plates to be cut coinciding with the joints were cut off from the surface with diamond cutter wheels. Afterwards, the joints of the cut plates and the directions of the plates were drawn with acetate

24 Mixture of AB-57 is compiled of C.M.C (carboxy methyl cellulose), ammonium bicarbonate, E.D.T.A (ethylene diamine tetraic acid), pure alcohol, acetone and water. 
pens on the American cloth and the surface was separated from the ground by long wedges. The old mortar, which has completely lost its bonding to the rear surfaces of these plates, was cleaned and made ready to be replaced again. As in the slabs, the floor, which was cleaned from rotten mortar, was prepared according to the original and was covered with the new mortar poured at the same level as the floor and the boards placed on this new mortar were leveled with the help of heavy trowels. At the last stage of the process, the cloths on the surface and PVA were cleaned through the application of hot water and the conservation operation ended (Fig. 21).

The Odeion stoa floor mosaic, whose restoration and conservation practices have been completed, should be isolated with various top coverings and side measures in order to keep the external effects minimized, with periodic maintenance every year until the design and implementation of the top roof cover is completed. For these purposes, the floor was covered using impermeable materials such as geotextile, styrofoam, fine sand and gravel.

\section{2. Odeion Auditorium}

The conservation work carried out in the Odeion was carried out by I. and II. cavea was undertaken during excavations in 2009 and completed with the intensive work program in 2013 and it includes the repair and consolidation practices of the seating steps.

With the first observations in the area, it was found that severe cracks and deformations had occurred as a result of exposure to excessive heat in the blocks forming the rows of seats in connection with the loss of the function caused by a large fire in antiquity. In addition, waterwind erosion occurring in the soil for a long period of time, expansion and pulling movement due to extreme temperature changes, pressure resulting from the freeze-thaw cycle of moisture, 'water-soluble salts' solution in the stone and crystallization of physical degradation, amongst other factors ${ }^{25}$. Therefore, the main purpose of the studies was to prevent the growth of the existing damages and the protection-repair applications were accordingly planned.
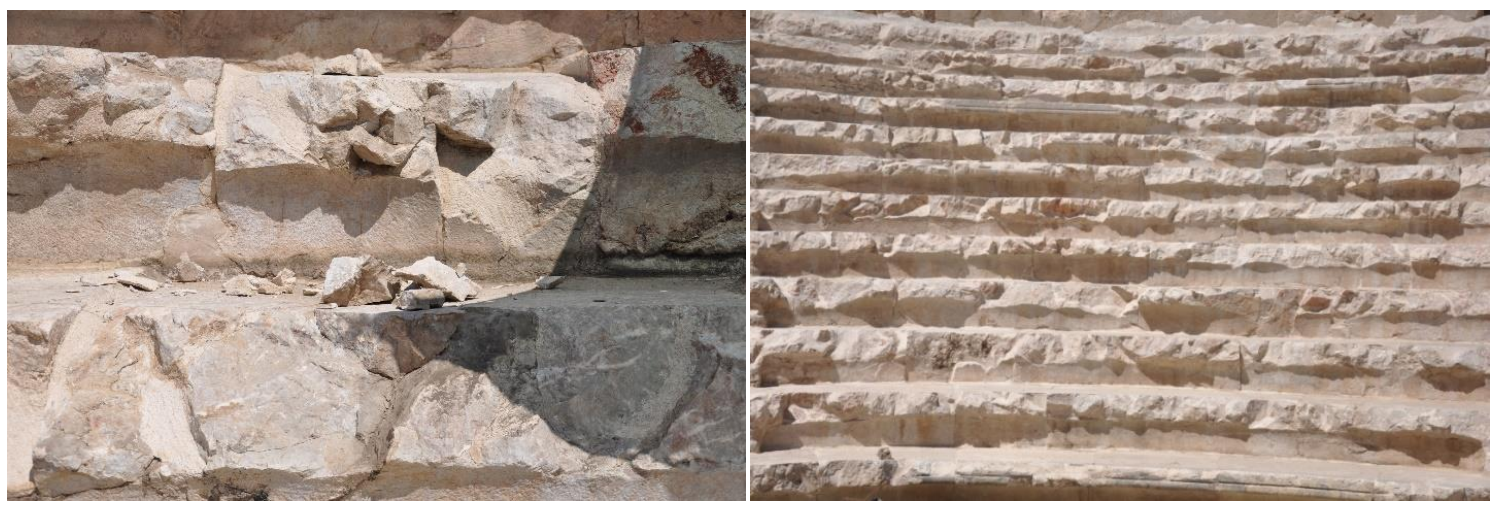

Fig. 22-23. Odeion Auditorium, before and after conservation (Kibyra Excavation Archive)

The first of the conservation studies was to fill the gaps in the interior of the stone by the cracks on the surface of the blocks. In this application, injection mortar, which has special properties, pozzolanic lime and micronized carbonates, which are suitable for the structural repair of masonry components, was used. Injected from all cracks, this fluid has the ability to fill the mortar up to the capillary cracks and so the penetration by water was prevented. After this preconcentration process, provided by injection applications, operations concerning the closure

25 Kariya - Nielsen 2002, 2. 
of the surface cracks began. The mortar required to cover the cracks was prepared with great care and applied with the same attention. The content of the mortar used in the application; hydraulic lime, 0-1 $\mathrm{mm}$. underglaze white sand, natural colorant and strength-enhancing property 0-1 $\mathrm{mm}$. The sieved brick-tile powder contained special packaging mortar and white acrylic, which were included in the mixture. All the cracks and gaps on the blocks of the rows of seats were filled with this mortar and thus the water and air intake into the stonework was prevented, with homogeneity provided to the surfaces of the blocks and thus the possible mechanical demolitions and openings that could occur with water-ice expansion, especially in the winter months was prevented (Fig. 22-23).

\subsection{Orchestra Opus Sectile Pavement}

Excavations in the Odeion were completed in 2009 and in 2014, with the decision of the Antalya Regional Directorate of Cultural Heritage Protection Board on 25.09.2013, the conservation of the orchestra flooring conservation was undertaken by Anka Restoration ${ }^{26}$.

The restoration work carried out by the experts in the field was started by determining degree of damage to the floor covering and the analysis of the material forming the floor. As a result of the preliminary evaluations made before the restoration work began, it was understood that in antiquity the wooden top cover of the building burned and collapsed onto the stage floor. As a result of the heat generated by this fire, as understood from the ruins of bronze objects that melted onto the pavement, the burn marks on the surface, the black ash layer and the ash residues observed when mixed with ground mortar (Fig. 24), it was determined that the heat generated by the fire caused serious damage to the physical structure of the stones forming the pavement and caused the formation of cracks and fractures in consequence of the expansion of the surface caused by the heat. In addition, the roof elements that fell down impacted on the pavement on reaching the ground. In accord with the original restoration applications documentation studies were carried out recording all these negative effects created by the destructive environment with the intention of protecting the floor and preventing further deterioration to the floor.

After the preliminary evaluations in the field, general and detail photographs showing general and first state deterioration of the pavement were taken, and then the area allocated to the squares in accordance with the designs was photographed in detail and 1/1 scale AutoCAD drawings were made. Thus, the plan of the elements of the pavement has been brought to the desired detail in order to facilitate the restoration work. After the completion of the digital drawings of the area, deterioration plates were created and all the problems were shown by means of these drawings.

In the technical researches carried out within the scope of the conservation and repair works of historical buildings, studies on the types of materials used in the original structure and the scientific determination of deterioration to them are very important. For these reasons, after the preliminary diagnosis and documentation studies in the field, implementation steps were determined and the intervention phase has begun. Steps of restoration operations were performed; all the parts of the stone mosaic pavement that had completely deteriorated from the ground mortar to be repaired, to make repairs with the new parts prepared with mortar layers to be repaired to the original, complete the missing parts, general joint work and surface cleaning after the completion of the areas to be painted in accord with the original plan. Finally,

26 Özüdoğru 2018, 140. 
with the repair of the pulpitum in the orchestra, the area was taken under protection and these aims were achieved.

The first stage of the planned process was to obtain the homogeneity of the parts that make up the floor from the ground. At this stage, the parts in their current position are removed and their fracture parts were assembled by means of double component glue and the mechanically detailed parts were cleaned with acetone to remove dust and foreign matter from their pores. Old lime mortar, which had lost its function on the ground after being placed in its current position, and the terracotta slabs, which were put in place for blocking, were removed by hand tools and the main base structure was reached in which the lime mortar could be more involved. Thus, a new lime mortar was applied to the floor and the pieces are fixed to this mortar. The content of this new fee; 2 scale river sand ( $0.2 \mathrm{~mm}$ aggregate length), 2 scale stone fracture $(0.2 \mathrm{~mm}$ and $0.1 \mathrm{~mm}$ mixed used in mixed form: Sandstone aggregate obtained), 0.75 scale tile fracture (1-2 $\mathrm{mm}$ thick), 0.75 scale tile fracture $(0.2-0.4 \mathrm{~mm}$ thick), 0.50 scale tile powder (thinner than 0.1 ) and 3 scale hydraulic lime. This disassembly and re-assembly was applied to the entire surface, so that the surface was brought in general to a uniform level.

All parts of the stage floor were repaired in the following way and the missing parts were filled with a mortar composed of finer aggregate mixture and their surfaces were levelled by spatulas. The reason for using more fine aggregate size of mortar in these integrations was to obtain a smoother and more accurate integration to the surface. The mortars made for the purpose of integration are made to the missing parts after freezing to some extent and the joints were cleanedwith the scraping technique in accordance with the overall pattern. In this way, the integrations are aesthetically aligned with the original sections. After the completion, the joint gaps formed between the floor slabs were filled with a thin lime mortar ${ }^{27}$ and visual integrity was ensured.

After the completion of the surface repair work, the cleaning phase began. Purification of harmful layers and salts on the surface intended for surface cleaning as also the cleaning of soot and burn spots. Before cleaning, the surface was swept and then the rough dirt layers adhering to the surface were removed with the help of scalpel and dentist tools. Ammonium bicarbonate solution prepared with $10 \%$ ratio was applied to the surface in certain sections and covered with paper pulp. Soil layers that soften the chemical solution were removed by mechanical tools (scalpel, soft brushes and dentist tools) and the surface was washed with clear water and the chemical effects removed.

After the surface cleaning was completed, the colours of the parts of the floor covering were more clearly seen. Thus, the shades of the paints which will be used in the dyeing areas of were determined with the examinations made on the colour scales and the appropriate paints and colours were selected accordingly. The integration areas of the pottery silicate-based and externally resistant paints and the parts of the floor covering were provided with the help of the templates taken from the sections and visual integrity has been provided to the floor.

After the completion of the restoration of the Odeion stage mosaic, restoration work began on the pulpitum façade, on which the long side of the stage rested. Most of the pulpitum processing of the modelling of the Odeion's facade architecture is missing, and after excavation, a large part of it has not been discovered. However, the fragments of the facade found during

27 A binder of acrylic origin, called Primal AC-33, is also included to allow this mortar to better adhere to fine ranges. This material increases the aggregate hold in the mortar itself as well as the better bonding of the mortar to the surface. 
excavation are sufficient to make local integrations. The pieces recovered from the ground are separated from the rear surface and they are heavily damaged by fire. It has been observed that this destruction is as it is on the stage floor, the water flow out of the wall joints in the rainy weather and the water rising from the floor formed from the bedrock penetrate through the processing plates and joints in the pulpitum and increased the deformation. For this reason, in order to complete the missing parts in the first phase of restoration that was started on the facade, the surface cleaning of the parts uncovered in the excavation works were made and the colour and forms of the parts were made more comformable.

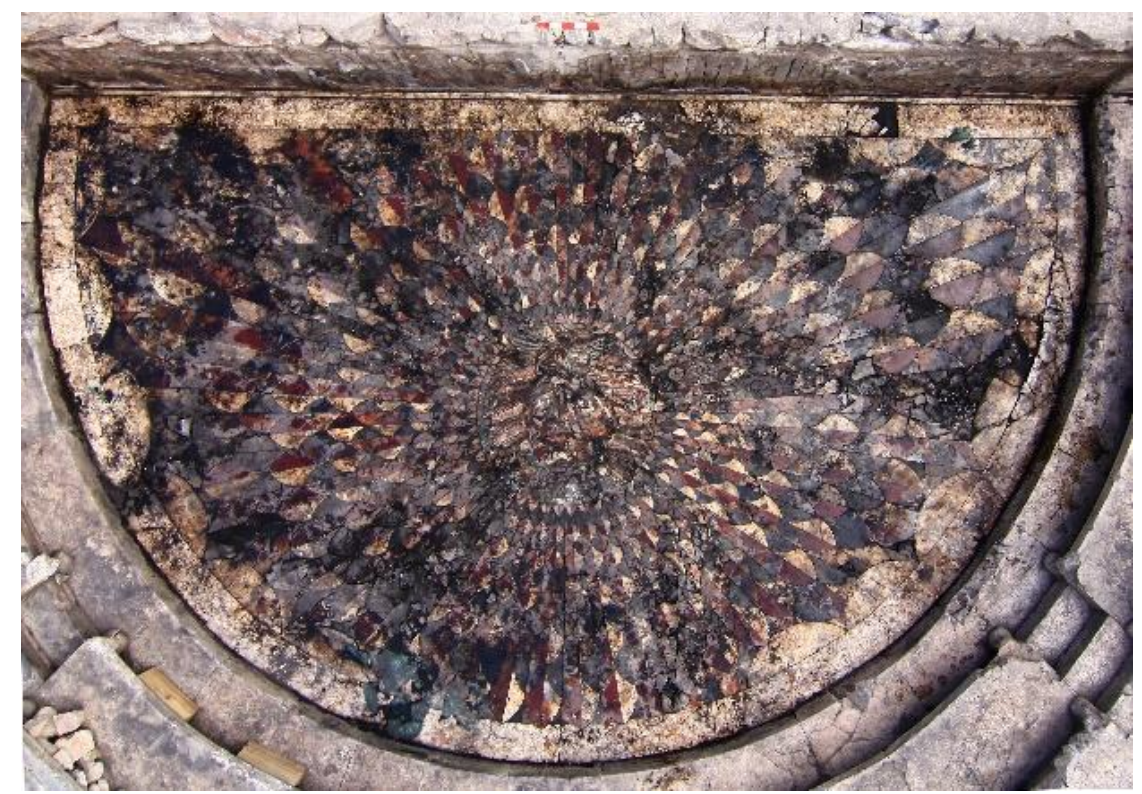

Fig. 24. Orchestra Opus Sectile Pavement, before conservation (Kibyra Excavation Archive)

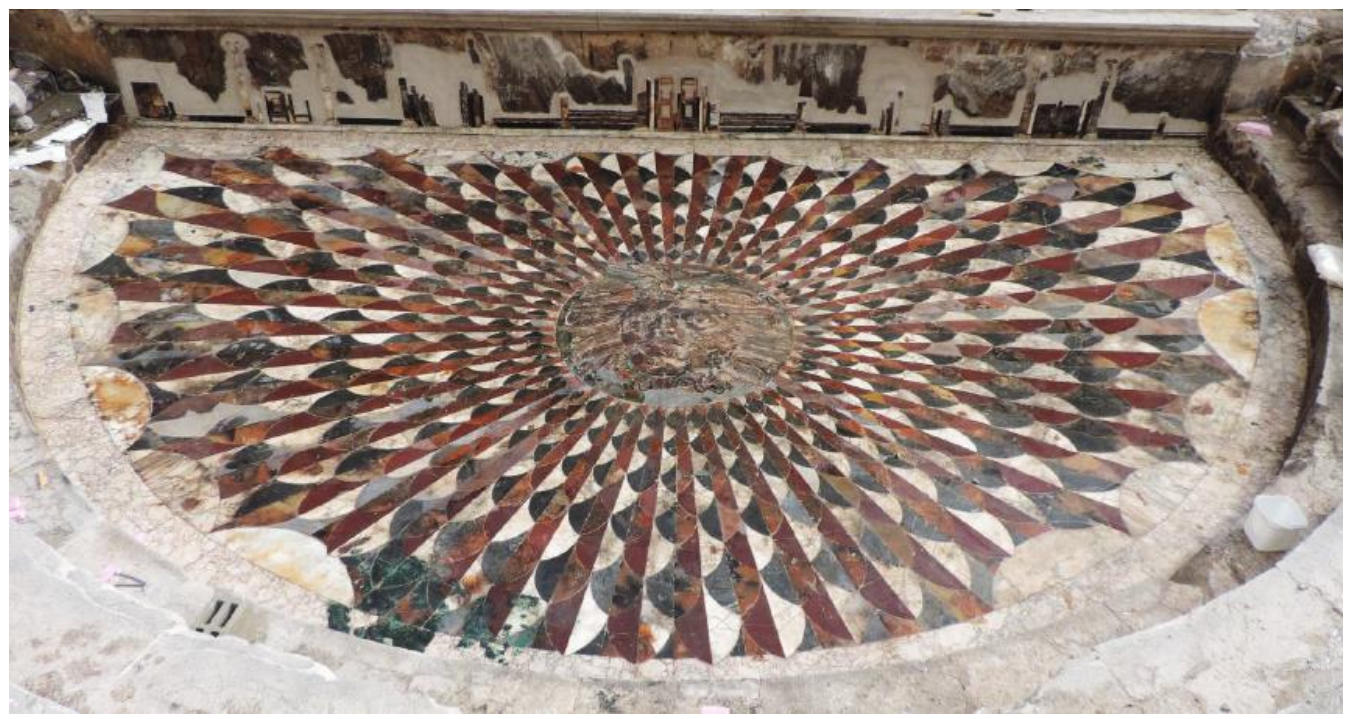

Res. 25. Orchestra Opus Sectile Pavement, after conservation (Kibyra Excavation Archive)

Afterwards, the parts were grouped according to their formal characteristics and found their own components and they were sorted into separate panels according to the parts they could belong to and their original positions were determined. With these parts found after the missing parts, in order to secure the in-situ parts in place and to be placed on a healthy floor, 
firstly the fixation to the floor was made with the main floor. For this purpose, the parts of the soil plates, which were used as blockage together, were separated from the wall by stainless screws and attached to the main wall and the spaces between the wall and the block were injected. After the repairs to the weakened material texture of the assembled parts, this new ground was reinforced with hydraulic lime-based mortar and the integration and consolidation at the front were completed. Thus, the general appearance of the facade today reflects the visual appearance of the facade in antiquity ${ }^{28}$ (Fig. 25).

\section{Roman Bath Complex}

As a result of the excavations carried out in 2015, it was determined that there were serious physical disturbances in the apse and the main walls of the ambulacrum, which constitute the main structure of the bathhouse in the north west (Fig. 26). In addition, the first impression is that small-scale flooring marbles that can be preserved in the apse centre, the original plasters on walls, and skirting samples found on the apse are also greatly damaged. Considering all these destructions, a rapid and effective conservation-anastylosis study was inevitable in the field against all kinds of threats due to the difficult weather conditions that will especially occur in winter season.

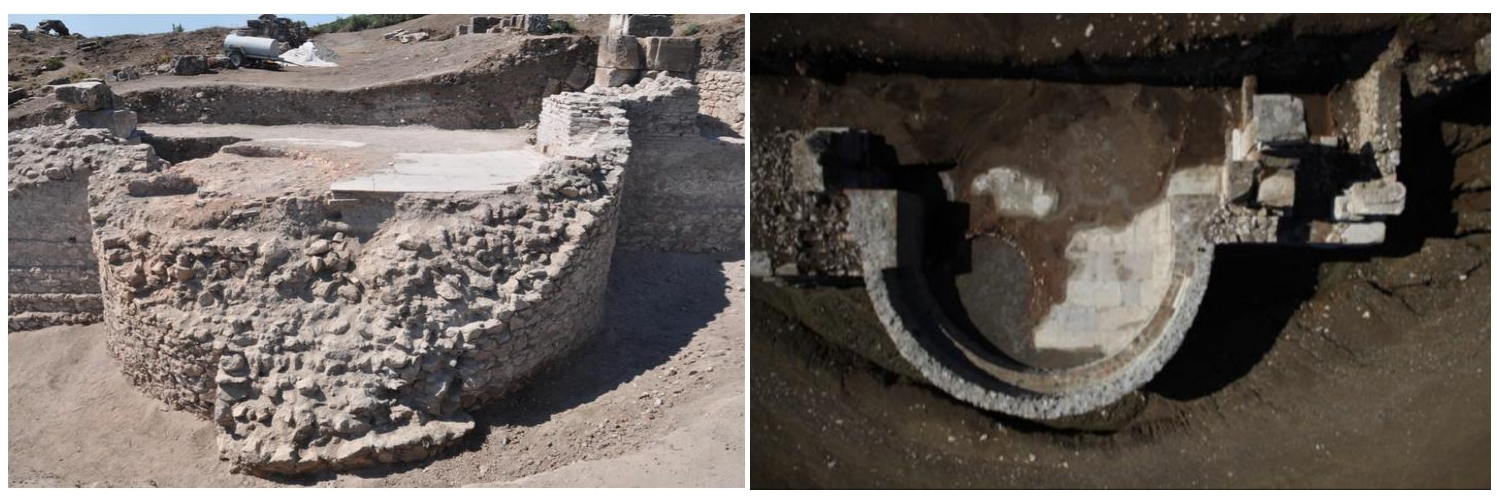

Fig. 26-27. Roman Bath Complex, before and after conservation (Kibyra Excavation Archive)

With this in mind, the conservation works initiated in the area have been carried out primarily in the apse given its poor condition. Firstly, the walls to be protected and repaired were washed completely with clear water and then the brick wall which forms the eastern starting corner of the apse was raised to the original wall level and the wall was blocked behind and its connection with the main rubble mesh wall was ensured. In all wall bonding works in this area, original stones belonging to the structure were used. In the second stage of the studies, bonding work was carried out to the main apse wall. Particularly the wall, which was largely destroyed due to earthquakes, was considered as a necessary condition for the future of the building with upgrade work to be carried out. For this reason, the wall, which was built with rubble stones, was increased to the same level as the brick walls of the apse.

During these works, all the architectural details of the building were determined very carefully and the architectural elements such as the living room in the apsis and the small pillar wall located outside the apse were reinforced according to the original. The mortar used during wall bonding applications was divided into two types. Mortar used in the masonry in the wall, hydraulic lime and 0-4 mm. aggregate. The grout used in the facade joints is $0-10 \mathrm{~mm}$. The

28 For a similar example of the application, see: Şener 1999, 193-201. 
subsoil contains natural conglomerate shaft and age lime. On the other hand, mechanical finishing method was applied to the surface joints with a certain consistency of the mortar, thus giving the appearance of a unity with the original texture of the structure.

In the inner part of the apse, the sitting set was covered with bricks on the surface in accordance with the original, and the rough workmanship of this area was completed. In addition, the skirting examples found at the western end of the section were re-studied for consolidation. The final phase of the conservation work was carried out to the interior walls of the apse and on the internal walls. The mortar used in these operations was 0-4 $\mathrm{mm}$. It consists of natural conglomerate shaft and hydraulic lime. First of all, the area has been completely protected, including the details of the plaster examples that can be preserved on the walls and then the outline of the small marble floor which was preserved on the apse floor (Fig. 27).

\section{East Necropolis}

In 2014, during the excavations carried out in the northern and southern flank of the Monumental Tomb in the Eastern Necropolis, the necessity of conservation and restoration practices against the regional severe climate conditions and human threats was of great importance. In this context, in the northern area, more static reinforcement applications were made and in the southern area, anastylosis applications were carried out on the podiums with the repair and planar association in the retaining wall. The eastern necropolis, which was found to belong to the

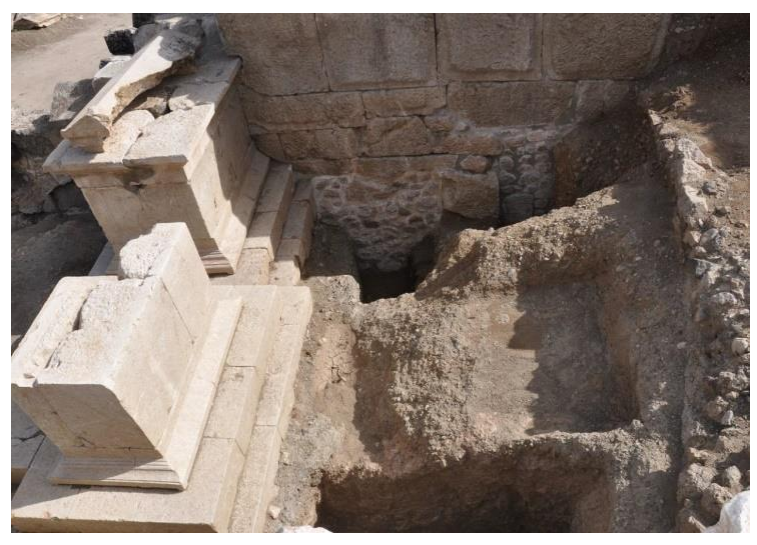

Fig. 28. Eastern Necropolis, retaining wall (Kibyra Excavation Archive) early period of the northern part of the necropolis, had to build a retaining wall in these areas due to the fact that the north wall of the monumental tomb placed on the grave tombs lost its static strength due to the base gap which was exposed after the excavations. For this reason, as a result of excavations, rubble stones were used and a masonry wall was constructed for safety purposes. The content of the mortar used in this wall, which is raised in a curved way from the grave floors to the bottom of the main wall; 0-6 $\mathrm{mm}$. The natural conglomerate shaft, hydraulic lime and the natural colorant red clay soil which are included mixed with pure water were used. After the completion of the bonding process, the joints of the walls were pressed to make them look natural. (Fig. 28).

In the southern part of the tomb, there was a major damage to the existing retaining wall due to an earthquake in the late period. Therefore, in this area, a conservation and repair work plan was developed in order to provide priority the for static reinforcement of the reinforcing wall. In the first stage, the original part of the existing masonry retaining wall extending on the north-south axis was repaired. The single face smooth rubble stones that were exposed and grouped during excavations were used on the basis of the priority of the original material during the repair applications to the wall. Then, the joints of the retaining wall were cleaned and debris removed by mechanical methods. The mortar used in the application is of the same quality and is 0-6 mm. natural conglomerate shaft, hydraulic lime and pure water. The same techniques and applications were carried out in room 14 in the deep dromos, which provided access to the grave. In addition, the porous railing, which was destroyed during the robbery on the door lintel 
in the grave dromos, was also integrated and preserved in its original place.

In the last stage of the studies, anastylosis applications of the catastrophes were carried out. Within this scope, all 23 stone blocks that were placed on grave podiums 7, 9 and 11 were repositioned directly into their original positions by using static weights without any chemical or physical binders. Thus, the small necropolis complex with podium sarcophagus tombs located in front of the chamber tombs achieved a great deal of its original appearance through regaining architectural integrity.

\subsection{Sarcophagus of the Monumental Tomb}

The semi-processed sarcophagus belonging to the monumental tomb in the eastern necropolis area of Cibyra was unearthed with its completely preserved intact lid and its body was seized in a large number of broken pieces (Fig. 29). The sarcophagus was destroyed in late Antiquity, when robbery caused the deliberate destruction of the two sides of the sarcophagus, and the two Medusa motifs carried on the narrow sides of the sarcophagus were connected to the narrower side faces of the niches in the corners and the Eros in the wreath. The rear part of the sarcophagus is coarse.

The first stage of the conservation work on this sarcophagus comprised the integration of the front face which was preserved in broken pieces. During this process the original locations of the broken parts were identified and their location on the sarcophagus was determined. Then, the limestone layer and microbiological patina on the joint surfaces of the original parts were cleaned by mechanical methods and bonded to the fracture fracture by two component epoxy resin. The original parts of the sarcophagus were fixed to their original position on the sarcophagus using an epoxy resin. In order to prevent the excess resin in the joint surfaces from being elevated and to ensure that the alignment of the sarcophagus is not disturbed, the portions joined with the ratchet rope were compressed. The excess resin overlying the surface was cleaned with a diamond-tipped chisel and pure alcohol to provide structural integrity to the front surface of the sarcophagus. However, cracks and crevices should be covered with chalky mortar $^{29}$ if necessary. For this reason, it was ensured that the sarcophagus was restored close to its original appearance by applying the filling application to the cracks and to the damaged-lost areas on the surface (Fig. 30).

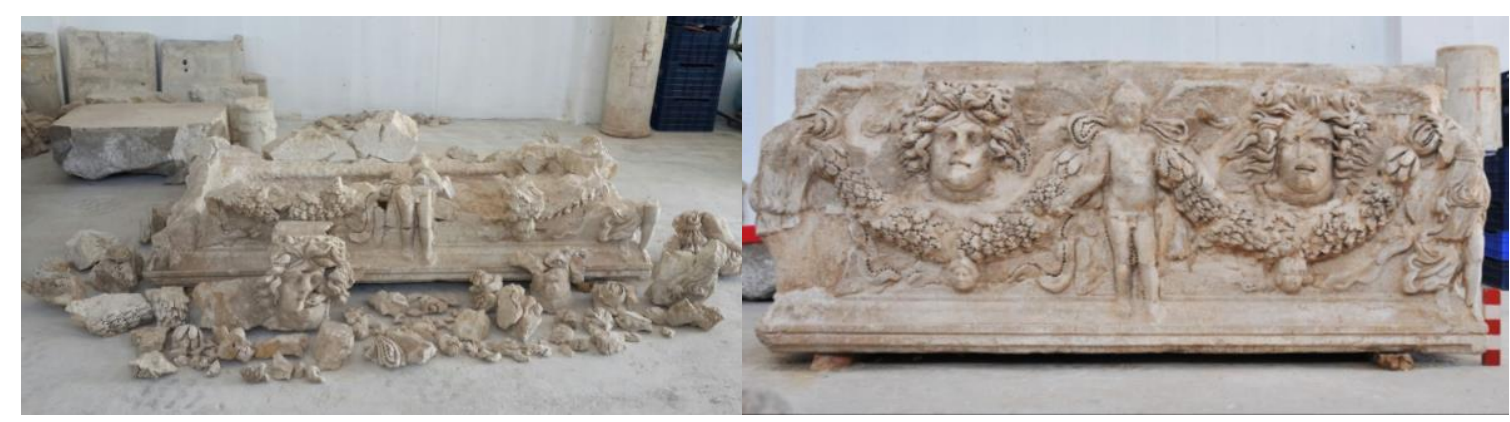

Fig. 29-30. Sarcophagus of Monumental Tomb, before and after conservation (Kibyra Excavation Archive)

After the process of integrating the fractures on the front surface, which formed the first stage of the study, the complementary application to the two side surfaces, which are less conserved than the front face, have been applied in the same way.

After the completion of the integration works of the front and sides of the sarcophagus, the

29 Şener 2013, 618. 
semi-finished rear facade of the sarcophagus was addressed using the moulding technique. In this respect, firstly, an internal mould was prepared with the aim of increasing the strength of the casting mortar by means of stainless chrome steel bars. In this application, $2 \mathrm{~cm}$ holes were drilled with coring drill to the inner fractures of the sarcophagus. These chromium steel bars were connected to the sarcophagus with the help of synthetic resin and reinforced by using stainless wire. In addition to this, external and internal backed wood moulds were formed in accordance with the dimensions of the finishing areas to be formed with lime-based mortar to the original texture and colour, and then moulds were cast for the prepared areas using limebonded mortar.

The content of the mortar used in these applications; hydraulic lime, 0-1 $\mathrm{mm}$. underglaze white sand, natural colorant and strength-enhancing property 0-1 $\mathrm{mm}$. sieved brick or tile powder and white acrylic. Two working days were expected for the removal of the moulds so that the complete firing process of the mortar could be completed in a healthy way. At the end of two days, the coarse grout flow of the moulded areas was cleaned with the aid of diamondtipped chisels and the fine mortar tools were cut in the mortar to the depths of the surface and was cut in accordance with the principles of ancient stone work. Thus, the conservation-repair application of the completed areas on the sarcophagus vessel was completed, allowing the sarcophagus to be restored to close to its original appearance and to be exhibited. 
Ahunbay 1996

Akıllı 1988

Akıllı 1989

Ang। 2014

Baytak 2015

Caner-Saltık 1999

Cronyn 1990

Dikilitaş 2010

Ekinci vd. 2007

Ersoy 1999

Heinz 2008

Kariya - Nielsen 2002

Kuban 2002

Küçük 1999

Özüdoğru et al. 2010

Özüdoğru et al. 2011

Özüdoğru et al. 2012

Özüdoğru et al. 2013

Özüdoğru 2018

Özüdoğru 2018a

Özüdoğru-Tarkan 2018

Peacher - Salzman 1999

\section{BIBLIOGRAPHY}

Z. Ahunbay, Tarihi Çevre Koruma ve Restorasyon. İstanbul 1996 H. Akıllı, "Mozaiğin Yerinde Korunması ve Onarımı". STAD 1/2 (1988) 113119.

H. Akıllı, "Mozaik Tahribatları". Anadolu Araştırmaları XI (1989) 165- 178.

S. Angı, "Kârgir Yapıların Koruma ve Onarım Çalışmalarında Doğal Taş Envanteri Hazırlanmasının Önemi ve Dünya'dan Örnekler". Kârgir Yapılarda Koruma ve Onarım Semineri VI, 02-03 Aralık 2014, IBB KUDEB Yayını. İstanbul (2014) 13-14.

i. Baytak, "Cibyra Antik Kenti'nden Yeni Bir Buluntu: Çok İ̧̧levli Bir Çeşme Yapısı”. Eds. Ş. Kazan, Mehmet Akif Ersoy Üniversitesi Teke Yöresi Halk Kültürü Uygulama ve Araştırma Merkezi Sempozyumu. I. Teke Yöresi Sempozyumu Bildiriler Kitabı I. Burdur (2015) 667-75.

E. Saltık - N. Caner, "Taş ve Seramik Eserlerin Özelliklerinin ve Bozulmalarının Koruma Amacıyla İncelenmesi". I. Ulusal Taşınabilir Kültür Varlıkları Konservasyonu ve Restorasyonu Kolokyumu Bildirileri, 6-7 Mayıs 1999. Ankara (1999) 107-119.

J. M. Cronyn, The Elements of Archaeological Conservation. London 1990.

G. Dikilitaş, "Arkeolojik Alanlarda Koruma".Restorasyon Konservasyon Çalışmaları Dergisi/6 (2010) 43-52.

H. A. Ekinci - Ş. Özüdoğru - F. E. Dökü - G. Tiryaki, "Cibyra Kazı Çalışmaları 2006. ANMED/5 (2007) 22- 28.

H. K. Ersoy, "Türkiye'nin Kültür ve Tabiat Varlıklarını Koruma Kanunu'ndan Alıntılar". Kazı Notları: Arkeolojik Konservasyon ve Antik Yerleşimlerin Korunması liçin Pratik Rehberler/5. Japon Anadolu Arkeoloji Enstitüsü (1999).

G. K. Heinz, "Arkeolojik Restorasyon Uygulamalarında Görülen Teori ve Pratik Çelişkileri". 4. Ulusal Yapı Malzemesi Kongresi ve Sergisi, 12-14 Kasım 2008. İstanbul (2008) 460-472.

H. Kariya - A. Nielsen, "Arkeolojik Kazılarda Taş Buluntuların Konservasyonu". Kazı Notları: Arkeolojik Konservasyon ve Antik Yerleşimlerin Korunması lçin Pratik Rehberler/13. Japon Anadolu Arkeoloji Enstitüsü (2002).

D. Kuban, Tarihi Çevre Korumanın Mimarlık Boyutu. İstanbul 2002.

C. Küçük, "Dünyada ve Türkiye'de Restorasyon Kavramı, Türkiye' de Yapılanma Sorunları ve Çözüm Önerileri". 1. Ulusal Taşınabilir Kültür Varlıkları Konservasyonu ve Restorasyonu Kolokyumu Bildirileri, 6-7 Mayıs 1999. Ankara (1999) 29-33.

Ş. Özüdoğru - F. E. Dökü, "Cibyra 2009 Yılı Çalışmaları", ANMED/8 (2010) 37-45.

Ş. Özüdoğru - F. E. Dökü - G. Dikbaş - H. Vanhavarbeke, "Cibyra 2010”. ANMED/9 (2011) 36-43.

Ş. Özüdoğru - F. E. Dökü, “Cibyra 2011”. ANMED/10 (2012) 46-52.

Ş. Özüdoğru - F. E. Dökü, "Cibyra 2012 Yılı Kazıları”, ANMED/11 (2013) 4754.

Ş. Özüdoğru, "Cibyra 2014-2016 Yılı Çalışmaları ve Sonuçları". Phaselis IV (2018) 109-146.

Ş. Özüdoğru, "Geç Antikçağ’da Cibyra”. Cedrus VI (2018), 13-64.

Ş. Özüdoğru - D. Tarkan, "Cibyra Geç Antikçağ Hamamı". Adalya 21 (2018) 175-211.

C. Peachey - E. Salzman, "Arazide Konservasyon Çalışmalarının Belgelenmesi". Kazı Notları: Arkeolojik Konservasyon ve Antik Yerleşimlerin Korunması İcin Pratik Rehberler/8. Japon Anadolu Arkeolojisi Enstitüsü (1999). 
Polat 2002

Sayın 2015

Sayın 2018

Severson - Ersoy 2002

Severson 1999

Strahan - Unruh 2002

Şener 1999

Şener 2012

Şener 2013
Y. Polat, "Antik Mozaiklerin Restorasyonu-Konservasyonu ve Kaldırılması". Anadolu Üniversitesi Edebiyat Fakültesi Dergisi/3 (2002) 287-305.

E. Sayın, Cibyra Antik Kentinden Opus Spicatum Döşemeler. Unpublished Master Thesis, Uludağ University, Bursa 2015.

E. Sayın, "Cibyra Kenti Agora I. Teras Caddesinde Yer Alan Zemin Döşemelerinin Koruma ve Onarım Çalışmaları". Sosyal Bilimlerde Güncel Akademik Çalışmalar/3 (2018) 99-117.

K. Severson - H. K. Ersoy, "Arkeolojik Kazılarda Mozaik Konservasyonu". Kazı Notları: Arkeolojik Konservasyon ve Antik Yerleşimlerin Korunması Için Pratik Rehberler/18. Japon Anadolu Arkeolojisi Enstitüsü (2002).

K. Severson, "Türkiye'de Arkeolojik Alanların Korunması". Kazı Notları: Arkeolojik Konservasyon ve Antik Yerleşimlerin Korunması Için Pratik Rehberler/10. Japon Anadolu Arkeolojisi Enstitüsü (1999).

D. Strahan- J. Unruh, "Arkeolojik Kazılarda Pişmiş Toprak Buluntuların Konservasyonu". Kazı Notları: Arkeolojik Konservasyon ve Antik Yerleşimlerin Korunması Için Pratik Rehberler/12. Japon Anadolu Arkeolojisi Enstitüsü (2002).

Y. S. Şener, "Knidos Duvar Dekorayonu Restorasyon-Konservasyon Çalışmaları (1996-1998)". 1. Ulusal Taşınabilir Kültür Varlıkları Konservasyonu ve Restorasyonu Kolokyumu Bildirileri, 6-7 Mayıs 1999. Ankara (1999) 193-201.

Y. Selçuk Şener, "Arkeolojik Alanda In-Situ Mozaik Koruma Yöntemleri". Journal of Mosaic Research AIEMA 5 (2012) 201-220.

Y. S. Şener, "Arkeolojik Alanda Yapı Malzemelerinin Korunması: Temel Yaklaşımlar, Yöntem ve Uygulama Biçimleri". Ed. Gökhan Tokdemir, Orhan Bingöl'e 67. Yaş Armağanı. (2013) 611-624. 